International Journal of Canadian Studies

Revue internationale d'études canadiennes
INTERNATIONAL JOURNAL OF CANADIAN STUDIES

REVUE INTERNATIONALE D'ÉTUDES CANADIENNES

\title{
Canada at War in the Pacific: The case of Complex Neorealism
}

\section{Mark S. Williams}

Numéro 37, 2008

Canadian Challenges

Les défis canadiens

URI : https://id.erudit.org/iderudit/040799ar

DOI : https://doi.org/10.7202/040799ar

Aller au sommaire du numéro

Éditeur(s)

Conseil international d'études canadiennes

ISSN

1180-3991 (imprimé)

Découvrir la revue

Citer cet article

Williams, M. S. (2008). Canada at War in the Pacific: The case of Complex Neorealism. International Journal of Canadian Studies / Revue internationale d'études canadiennes, (37), 167-176. https://doi.org/10.7202/040799ar 


\section{Mark S. Williams}

\section{Canada at War in the Pacific: The Case of Complex Neorealism}

\section{Introduction}

In his seminal genealogy of international relations, Steve Smith $(1995,2)$ reminds his readers that "silences are the loudest voices" of a discipline. Similar to those of sociology on the Holocaust, the silences of international relations are found in the international itself. Derided as barbaric, irrational, and of course anarchic, international relations often fails to articulate the space of the international as socially constituted by interpretation and identity (2-3). This paper will attempt to address a number of the disciplinary silences of international relations, such as 1) those between international relations and foreign policy analysis, 2) Canadian foreign policy, traditionally analyzed only after the Second World War, and 3) the role of identity in international politics. The first section discusses the theory of complex neorealism as that which integrates international relations with foreign policy analysis, and will be applied to Canada during the Second World War. The second section is divided into two principal areas: 1) Mackenzie King and Canada entering the Second World War, and 2) Canada's war in the Pacific in particular. The final section of this paper will consider the relevance of the English school of international politics both during the Second World War and after. This paper argues that the weakness of complex neorealism in explaining Canada's decision to declare war is principally due to the theory's failure to meaningfully incorporate identity into its framework.

\section{Complex Neorealism}

Canadian scholars have a tradition of integrating theories of international politics with Canada's foreign policy (Nossal 1997). David Dewitt and John Kirton offer a detailed modification of neorealism described as "complex neorealism" to integrate the theory of international relations neorealism with foreign policy analysis in the context of Canada. Complex neorealism applies to a state regarded as a "principal" power, analogous to the former Great Powers of the 19th century Concert of Europe. The components of complex neorealism are: 1) defence of national interests and promotion of distinctive values, 2) principal powers acting in concert with each other, and 3) principal powers acting to modify the international order to reflect their interests and values (Dewitt and Kirton 2007,37-38). These 
aspects are justified by three main arguments presented by Dewitt and Kirton (1983, 5-7).

The first justification is that complex neorealism is being introduced to a Canadian context that has historically consisted of a debate between liberal internationalists and peripheral dependency theorists. The second justification is that the three components of complex neorealism provide a theoretical depth useful for bridging international politics with Canadian foreign policy analysis. The final justification for the three aspects is that they can be engaged to decide which is the most convincing and temporally robust for the student of Canadian foreign policy.

Kirton explicitly maintains that the theory of complex neorealism was dominant in Canadian foreign policy during the 1960 s, in Trudeau's first term and when Canadian aid was first being directed toward francophone countries (2007, 29-30; Dewitt and Kirton 2007, 34). However, complex neorealism is also used as a theory to explain Canadian foreign policy prior to the late 1960s. The Second World War receives very little attention in either of Kirton's textbooks. Both clearly state they are concerned with the postwar order, but complex neorealism is the salient theory used to explain Canada's foreign policy. Dewitt and Kirton suggest that Prime Minister Mackenzie King's decisions to enter the Second World War and contribute to the Allied war effort are indicative of Canadian support for Great Britain and the maintenance of the global balance of power $(1983,13,320)$. Kirton suggests that support for Great Britain was not primarily due to the Canadian identity in the Commonwealth, but was power politics containing "the seeds of the complex neo-realist pattern of Canadian foreign policy" $(2007,48)$.

Kim Richard Nossal posits that Dewitt and Kirton acknowledge the relevance of domestic actors in their discussions on complex neorealism, yet they do so only in passing. The theory, while suggesting a role for domestic actors regarding international politics, ultimately fails to meaningfully contribute to the state-centrism typified by realist literature (2007, 169). Nossal's critique of Dewitt and Kirton focuses on the tension within complex neorealism of the avowedly statist orientation of the theory with its influence from Stephen Krasner, and the putative salience of domestic actors hesitantly acknowledged by Dewitt and Kirton. How social factors like identity can be integrated with the statism of complex neorealism is a silence of the theory that becomes problematic in the discussion on Canada leading up to and during the Second World War.

The next section of this study will first discuss Canada's entry into the Second World War in general, and then treat Canada's role in the Pacific as a case study. While the Second World War is not discussed in great detail by Dewitt or Kirton, justification of it as an appropriate subject for inquiry regarding complex neorealism might be emphasized on two levels: 1) the 
war is suggested as the starting point of complex neorealism in later Canadian foreign policy, 2) the war is significant, both for those Canadians who fought and died and in having shaped Canadian foreign policy in the postwar period.

\section{Mackenzie King's War}

Canada declared war on Nazi Germany on 10 September 1939 and later on the Empire of Japan on 8 December 1941. The subsequent section will consider Canada's war in the Pacific, but will provide the context for the discussion on the war against Japan by first discussing the worldview of Prime Minister William Lyon Mackenzie King and the context of Canada's entry into the war. It will be argued that Mackenzie King's entry of Canada into the war must be interpreted by considering both the normative dimension of his view of international politics and the importance of identity.

\section{The Normative Argument}

To appreciate the worldview of Mackenzie King, one must consider the normative argument for a global society that is repeated during the interwar period as well as during the Second World War. In an address on citizenship given in August 1925, Mackenzie King discussed Canada's national unity, its role in the British Empire, and the question of the League of Nations. Mackenzie King's argument was that Canada must embrace all three of its duties: national citizenship, empire citizenship, and world citizenship $(1927,150)$. He propounded a broader international participation for Canada because "in a world which has become one, we cannot live unto ourselves" (145). Canada was encouraged to have an international role to promote a more just world order: "The world's security lies in having like ideas and ideals made to prevail over as wide areas as may be possible" (ibid.).

The normative reflections of Mackenzie King are a strong rebuttal to complex neorealism's assertion of the primacy of power politics defining Canada's entry into the Second World War. It is power politics that Mackenzie King blames for the outbreak of the war. In a diary entry dated 28 September 1938, before the Munich Crisis, Mackenzie King wrote about the nature of European power politics being expressed and about a pejorative charge that he was "chivalrous":

To be influenced by this judgement would be equivalent to admitting that material interests could be greater than moral interests of [sic] spiritual. I will never descent [sic] in to that pit. I would be quite prepared to sacrifice my own life at the head of the nation, than to see it buried in a materialistic slough, or bowing before a brutal God of Fear and Force. 
Mackenzie King's distaste of power politics is further evident in a vision he said he experienced between 6:00 and 8:00 in the morning on the eve of war with Germany. The latter part of the vision involved Ralston, Canada's minister of national defence, standing in a room where, opposite, two men were shot. Mackenzie King believed that the appearance of Ralston represented Canada's victory in the war due to both the country's finance and the "finest of Canada's effort" - that is, chivalry (King Diaries, 8 September 1939).

In his address to the House of Commons on 8 December 1939 to win support for the coming declaration of war, Mackenzie King equated the defence of Canada and Great Britain with freedom (1941, 7). For responsibility of the war, he quoted Hitler at length, demonstrating how Hitler attempted to justify peace in Europe through a political philosophy of power and domination. Mackenzie King argued that force was capable of achieving "nothing," and that Europe would only experience peace by cultivating an international system that resembled more of an integrated society (20-23).

The Nazis and the Japanese, in contrast, represented "those who worship[ped] material power" (King 1944, 216). The Third Reich and the "co-prosperity sphere" of imperial Japan were derided by Mackenzie King as systems of inequality both between races and within them (205). The portrayal of the struggle against Nazi Germany and the Empire of Japan as a battle between slavery and freedom was a recurring theme in Mackenzie King's speeches, along with the reference to Abraham Lincoln's famous quotation from the Gospels that a house divided could not stand (23-26, 205). Mackenzie King broadened Lincoln's context from that of a half-enslaved, half-free country to the world: a world both half-enslaved and half-free cannot endure.

\section{Identity}

Mackenzie King articulated ideas of multiple and cohabiting identities: national, North American, British, and global society. For him, all four were intrinsically interconnected; they will thus be discussed in relation to each other. Canadian national unity was important, not in the context of a realist formulation of Canada's national interest as interpreted by power politics, but in the context of the debate on conscription. Keenly aware of the Anglophone-Francophone tension precipitated by conscription during the First World War, King wanted to make electoral promises regarding any future conscription during the Second World War (King Diaries, 3 February 1940; Pickersgill 1960, 22; King 1944, 10).

The North American identity is articulated by Mackenzie King in three speeches given to American audiences between 1909 and 1927. The speeches refer to the "one hundred years of peace" that Canada and the 
United States had been able to maintain since the War of 1812 . This lasting continental peace had been achieved by the active engagement and commitment to peace of policy makers responsible for the Rush-Bagot Agreement of 1817 and the International Joint Commission of 1911, but more importantly because of the "community of interests, ideals, and aspirations" that had made "Reason supreme over Force" (King 1927, 166, $172,176)$. Mackenzie King suggested that the durable peace that had been held between Canada and the United States could be an example to the world and a goal Europe could aspire to (165): "This is the great object-lesson which we of the New World have to give to those who come to us from the Old" (176). The North American identity Mackenzie King advocated in his three afore-mentioned speeches was intrinsically an "English-speaking" one with Canada representing the British Empire $(177-78)$. The North American identity was inherently connected to the British Empire and later to the Commonwealth, and was the ultimate reason Canada declared war on Nazi Germany in 1939.

Before the war, Mackenzie King famously remarked to Adolph Hitler "that if Germany should ever turn her mind from constructive to destructive efforts against the United Kingdom all the Dominions would come to her aid and that there would be great numbers of Canadians anxious to swim the Atlantic" (Granatstein 1990, 2). Mackenzie King claimed that his admonition was not "the automatic response to some mechanical organization of Empire" $(1944,3)$ but rather a declaration of war based on an identity of the new world and the British Empire: "Canada is a nation of the New World. As a nation of the New World, we placed ourselves at Britain's side because Britain's cause was the cause of freedom, not in this island alone, not in the British Empire alone, not in the Old World alone, but everywhere in the world" (ibid.).

In the same address given in London, England, in 1941, Mackenzie King related the conflict to the Book of Revelations, in which the old world destroys itself and the new world order is based on the successful peace of the new world and its promotion of common ideals throughout humanity (11-12).

A very brief review of secondary sources on Canada in the Second World War largely supports the argument of identity outlined here. James Eayrs $(1975,194)$ stresses the moral superiority of the new world compared to the old world of Europe among the Canadian public generally and especially with reference to Mackenzie King. J.L. Granatstein (1990) argues that Canada entered into the war with its colonial ties to Britain largely intact, and emerged after the war as a fully independent state. Granatstein emphasizes that Canadian nationalism did not exist prior to the war, but rather was a force that Mackenzie King shaped and directed during the fighting. According to Granatstein, Canada did not enter the war to defeat Nazism, anti-Semitism, or to free Europe: "Canada was in the war out of a 
sense of duty, not because her own national interests were directly threatened" (42). Despite Mackenzie King's concerns regarding national unity and his suspicions surrounding Great Britain, Canada went to war because Britain was at war.

\section{The War in the Pacific}

Canada's involvement in the Pacific War has not been the subject of much scholarly scrutiny, nor was it even reported much in the news media of the time. However, it can be divided into three main sections: 1) Hong Kong, 2) the Aleutian Islands, and 3) the negotiations of Canada's contribution leading up to Okinawa. Canada's involvement in the Pacific War must be interpreted in the context of the country's entry on the European stage two years earlier.

\section{Hong Kong}

Canada's declaration of war on Japan, issued on 8 December 1941, was different from the declaration against Germany issued over two years previously, yet it was within the same context. As mentioned earlier, Canada declared war against Germany because Great Britain had just declared war. The country then declared war against Japan because her soldiers garrisoned on Hong Kong had been attacked on 7 December. As a British colony, Hong Kong was garrisoned by British forces, and in 1940 Canada had been asked. to send soldiers. The events leading to the deployment of Canadian troops in Hong Kong are not entirely clear, but they began with Major General A.E. Grasett, former general officer of the British Hong Kong outpost, who was travelling through Canada on his return to Britain. Grasett met with the chief of the Canadian general staff, Major General H.D.G. Crerar, to petition the addition of two or more Canadian battalions to reinforce the outpost at Hong Kong. The correspondence between high-level Canadian officials and their British counterparts on Hong Kong significantly downplayed the danger the Empire of Japan represented to the outpost, and made the decision based on political and moral reasoning rather than questioning the military danger troops would be exposed to on Hong Kong (Vincent 1981, 39-43). Ultimately, two battalions were selected to be deployed to the ill-fated island, representing both eastern and western Canada: the Winnipeg Grenadiers and the Royal Rifles of Canada, totalling 1,975 soldiers. These troops had previously been garrisoned in the West Indies and Newfoundland. The inquiry of the Hong Kong Commission on the battle readiness of these troops has been highly criticized (36-37).

In three of his diary entries (3 July 1940 and 15 and 16 November 1941), Mackenzie King equated the contribution of Canadian soldiers to Hong Kong with the defence of Canada. Despite the shelling of Estevan Point on Vancouver Island by a Japanese submarine on June 21, 1941, Canada's 
sovereignty was not seriously threatened at this time. Soldiers were sent to Hong Kong because the British Empire was being explicitly threatened by Japan. The urgency of the British request for soldiers to garrison Hong Kong in 1940 was enough for troops to be sent to the Pacific and even threatened a conscription crisis in Parliament (Pickersgill 1960, 315-17). While the Japanese had declared war on both the United States and the British Empire, attacking Hong Kong and Pearl Harbour on the same day, Mackenzie King made clear that it was the attack on Great Britain that directly led to Canada's own declaration of war (298).

\section{Aleutian Islands Campaign}

The Aleutian Islands campaign represents the second stage in Canada's contribution to the war in the Pacific. In early June 1942, the Japanese attacked the islands Attu and Kiska off Alaska. Following nine months of Japanese occupation, the Allies first invaded Attu Island and then Kiska Island three months later, the latter assault including a sizeable contingent comprised of almost 5,500 Canadian soldiers (Roehrs and Renzi 2004, 116-17). In Mackenzie King's speech to the Canadian public a week after the landings on Kiska, he discussed how most of the Canadian war effort was concentrated in the European and Atlantic theatres. He admitted that most Canadians were not even aware of the battles in the Pacific and that even "the defence of this continent against Japanese aggression [was] comparatively little known" (King 1944, 261). After the Japanese had launched their original assaults on Alaska, Roosevelt asked Mackenzie King whether public opinion in British Columbia was at all concerned with the Japanese attacks. Mackenzie King dismissed Roosevelt's query and they both agreed that British defeats in Egypt and Hitler's invasion of Russia were higher priorities (Pickersgill 1960, 415).

While Canadian forces in the European theatre experienced by far the heaviest casualties, these losses were more easily accepted and identifiable as necessary for the preservation of freedom compared with those losses suffered in the Pacific War. The Hong Kong disaster, on the other hand, quickly precipitated the establishment of a commission to investigate political and military negligence. The raid on Dieppe resulted in far more casualties, but no comparable commission was instituted to investigate incompetence.

What perhaps most reveals the low importance attached to Canada's contribution to the Aleutian Islands campaign is the use of Canadian forces conscripted under the National Mobilization Act. To avoid a national unity crisis over conscription, Mackenzie King promised that the soldiers drawn into service by the National Mobilization Act would not be used as combat troops. The decision to send conscripted Canadian troops to the Aleutian Islands was not made by Mackenzie King; he was not even notified of the decision until the troops were already en route to Alaska and could not be 
called back. Even after the contributions of those Canadian forces were announced to the public, there was no measurable political public outcry. Canadians were not following the Pacific campaign and were instead distracted by the participation of Canadian forces in the Allied invasion of Sicily (Pickersgill 1960, 515-17).

\section{Build-up to Okinawa}

The Canadian contribution to the Pacific after the Aleutian Islands campaign can be considered a military interregnum akin to Canada's military contribution during the first year after the declaration of war against Germany. The period between September 1943 and March 1945 is best represented by Canada's lack of participation in the war in the Pacific. This can be understood as both a sense of unwillingness of the part of Canada and a lack of urgency of the part of the Allies to induce Canada to participate.

Mackenzie King's position during Allied meetings of the war cabinets to discuss the Pacific was that Canada would not actively contribute combat troops for three principal reasons. The first was that Britain and the United States wished to reclaim territory lost to the Japanese, such as Singapore for the British and the Philippines for the Americans, which had nothing to do with Canada (Pickersgill and Forster 1968, 62). The second reason is illustrated in the introduction to the second volume of The Mackenzie King Record. Pickersgill and Forster contend that the focus for the Canadians, in contrast to that of the Americans, was absorbed by the campaign in Europe (9). Mackenzie King was clearly very conscious of the apathy of Canadians regarding the Pacific. To compensate, the prime minister very rarely publicly discussed Japan without a reference to Germany or Europe. His aim was to link the Axis powers as closely as possible and to overstate the cooperation and mutual goals of Japan and Germany, to blur the distinction between Europe, where Canadian identity was strong, and the Pacific, where the identity of Canada was much weaker (350-51). The prime minister's final reason for not contributing more combat troops was simply that he wanted to keep Canadian troops concentrated in Europe; he did not want to have to conscript more forces because of the war against Japan.

Mackenzie King would not commit combat troops to the Pacific campaign until the war moved north of the equator. The Mackenzie King Record states that this is because Canadians believed that the war in the Pacific was an imperial conflict for the British and Americans (Pickersgill and Forster 1968,73-79). This final point demonstrates both the strength and the weakness of Canadian identity with Great Britain. Canadian forces were in the Pacific originally because Great Britain had requested Canadian forces. However, support for the Commonwealth did not equate with support for the Empire. Canada's identity. as a state without colonial interests created a lack of support for the imperial interests of Great Britain 
in the South Pacific. While Canadian naval forces continued to have a presence in the Pacific during the war as small contingents attached to British regiments, such as in Burma and Sumatra, it was not until the Battle of Okinawa, in which Canadian naval and air forces neutralized the Japanese airfields in the nearby Sakishima Islands, that Canada became an active contributor to the Allied effort in the Pacific.

\section{Discussion}

As mentioned earlier, Canada entered the war against Nazi Germany because Great Britain entered the war, not out of an analytical calculation of self-interest or a desire on the part of Mackenzie King to engage in European power politics ascribed to Canada by complex neorealism. Rather, the context of Canada's declaration of war must be understood in relation to Mackenzie King's identity of Canada as bound to the Commonwealth and Great Britain, and his normative understanding of international politics and Canada's role as a part of a "New World" in which peace and interest was institutionalized to an international society, in juxtaposition to the "Old World" of European diplomacy and balance of power. The case study of the Pacific campaign during the Second World War elucidates Canada's involvement as a direct consequence of British influence, but also demonstrates the lack of a strong attachment of the Pacific. Britain's colonial possessions were not included as part of the new world to be defended by Canada, and were perhaps understood as outside of the international society of North America and the Commonwealth.

The relevance of this study is not isolated to the Second World War but continues into the postwar period. In his "Foundations of Canadian Policy in World Affairs" Grey Lecture, Louis St. Laurent discusses both the importance of Canadian national unity and the international society of the non-communist and specifically Christian world. It is also difficult to interpret the years of "Pearsonianism" without some discussion on the international society Pearson attempted to moderate during crises such as Suez and Cyprus.

\section{Bibliography}

Beier, J. Marshall. 2005. "Canada: Doubting Hephaestus." Contemporary Security Policy 26 (3): $431-46$.

Dewitt, David B., and John J. Kirton. 2007. "Three Theoretical Perspectives." In Readings in Canadian Foreign Policy, ed. Duane Bratt and Christopher J. Kukucha. pp. 27-45 Don Mills, ON: Oxford University Press.

1983. Canada as a Principal Power. Toronto: John Wiley and Sons.

Eayrs, James. 1975. "The Low Dishonest Decade." In The In-Between Time: Canadian External Policy in the 1930s, ed. Robert Bothwell and Norman Hillmer. pp. 194-201 Toronto: Copp Clark Publishing.

Granatstein, J.L. 1990. Canada's War: The Politics of the Mackenzie King Government, 1939-1945. Toronto: Oxford University Press.

King, William Lyon Mackenzie. 1944. Canada and the Fight For Freedom. Toronto: T. H. Best Printing. 
941. Canada at Britain's Side. Toronto: The Macmillan Company. 1927. Message of the Carillon. Toronto: The Macmillan Company.

Kirton, John J. 2007. Canadian Foreign Policy in a Changing World. Toronto: Nelson.

Library and Archives Canada. "The Diaries of William Lyon Mackenzie King." Collections Canada. Http://king.collectionscanada.ca/EN/default.asp.

Nossal, Kim Richard. 2007. "Analyzing Domestic Sources of Canadian Foreign Policy." In Readings in Canadian Foreign Policy, ed. Duane Bratt and Christopher J. Kukucha. pp. 163-175 Don Mills, ON: Oxford University Press.

- 1997. The Politics of Canadian Foreign Policy. Toronto: Prentice-Hall.

Pickersgill, J.W. 1960. The Mackenzie King Record, Volume I: 1939-1944. Toronto: University of Toronto Press.

Pickersgill, J.W. and D.F. Forster. 1968. The Mackenzie King Record, Volume II: 1944-1945. Toronto: University of Toronto Press.

Roehrs, Mark D., and William A. Renzi. 2004. World War II in the Pacific. New York: M.E. Sharpe.

Smith, Steve. 1995. "The Self-Images of a Discipline: A Genealogy of International Relations Theory." In International Relations Theory Today, ed. Steve Smith. pp. 1-37 University Park: Pennsylvania State University Press.

Vincent, Carl. 1981. No Reason Why: The Canadian Hong Kong Tragedy - An Examination. Stittsville, ON: Canada's Wings. 